Full-text Available Online at www. bioline.org.br/ja
J. Appl. Sci. Environ. Mgt. June 2006

Vol. 10 (2) 153 - 158

\title{
Hydrobiological Study of Algae of an Urban Freshwater River
}

\author{
${ }^{* 1}$ JAFARI, N G; ${ }^{2}$ GUNALE, V R \\ ${ }^{* 1}$ Department of Environmental Sciences, University of Pune, India. \\ ${ }^{2}$ Department of Botany, University of Pune, India.
}

\author{
Ph: $+91-20-56289792$ \\ Mailing address: N. Jafari, Flat No. 4, 2ND Floor, Ashiyana Terraces, Shivalaya Society, Sus Road-Pashan, \\ Pune-411021-India.
}

\begin{abstract}
Biological assessment is a useful alternative for assessing the ecological quality of aquatic ecosystems since biological communities integrate the environmental effects of water chemistry. Algal and water samples were collected at monthly intervals from three sites of River Mutha (Pune, India). The most pollution tolerant genera and species of four groups of algae were recorded from three sites of River. Nygaard's and Palmer's biotic indices have been used for the assessment of quality of the River. Phytoplankton encountered in the water body reflects the average ecological condition and therefore, they may be used as indicator of water quality. The algal flora of polluted water bodies shows the dominance of blue green and diatoms like, Oscillatoria, Lyngbya, Anabena, Microcystis, Navicula, Nitzschia, Synedra, Gomphonema through out the investigation many green algae like, Pandorina, Scenedesmus, Stigeoclonium, Ankistrodesmus, Chlamydomonas, also occur abundantly and frequently. @JASEM
\end{abstract}

Chemical analyses of water provide a good indication of the chemical quality of the aquatic systems, but do not integrate ecological factors such as altered riparian vegetation or altered flow regime and therefore, do not necessarily reflect the ecological state of the system (Karr et al., 2000). Biological assessment is a useful alternative for assessing the ecological quality of aquatic ecosystems since biological communities integrate the environmental effects of water chemistry, in addition to the physical and geomorphological characteristics of Rivers and lakes (Stevenson and Pan, 1999). Phytoplankton encountered in the water body reflects the average ecological condition and therefore, they may be used as indicator of water quality (Bhatt, et al., 1999; Saha et al., 2000).

Algae are frequently found in polluted and unpolluted water and due to this behaviour they are generally considered useful to determine the quality of water. These are very suitable organisms for the determination of the impact of toxic substances on the aquatic environment because any effect on the lower level of the food chain will also have consequence on the higher level (Joubert, 1980). Algae are used for assessing the degree of pollution or as indicator of water pollution of different water bodies (Trivedy, 1986; Sudhaker et al., 1994; Dwivedi and Pandey, 2002).

Area of study: Pune city, at the south west of India is situated on the banks of the confluence of the Mutha and Mula Rivers, at an altitude of over 585 meter above the sea level. The archaeological relics prove that Pune was established as a township in eighth century. Presently the city is under continuous stress due to population growth, industrial growth and waste generation. This city is the seventh ranking industrial metropolis of India. Along with the industries there is also increase in population of the city. In 1990, Population of Pune city was 1.52 million while increased to 2.5 million in 2005. The climate is typical monsoonal, with three distinct seasons, summer, rainy and winter. Mutha River which is one of the main River of the city, runs through the heart of Pune. This River once used to increase the glory of the city, but now had got an ugly look and turned out into a main source of dumping sewage, drainage and other waste (Fig. 1) Vitthalwadi (Site 1), this site is like a sub-urban area situated along the banks of the River Mutha, and now growing at a very fast rate. There are numerous activities, into its catchment's area such as new constructions, domestic utilization of water for washing of cloths, utensils and animals, activities such as fishing are the main occupation of some of the residents staying at this site along the Riverbank. Garware Causeway (Site 2), this site receives waste from Parvati and Kothrud area. The major activity on this site includes use of River water by washerwoman, with lot of use of soap and detergents. Sangam Bridge (Site 3), this site marks the confluence of Rivers Mutha and Mula. At this site, the additional domestic waste joins from Kasba area. At this site, the River water is more stagnant due to weir at Bund Garden and because of the confluence of Mutha with the River Mula. 


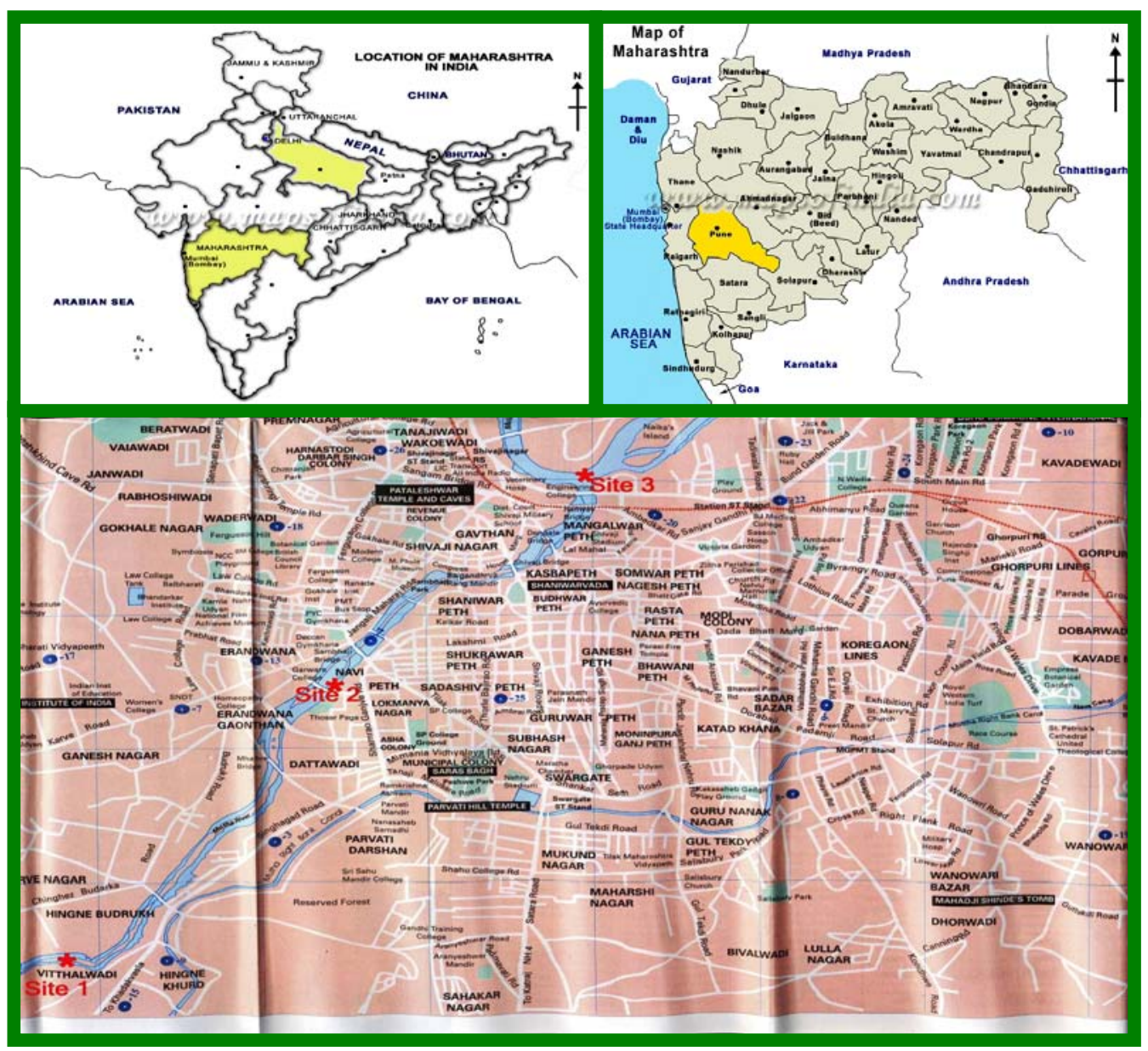

Fig 1. Map of study area showing location of Pune and sampling sites

\section{MATERIALS AND METHODS}

The water samples for phytoplankton analysis were collected from three sites of River for a period of 11 months starting from October 2004 to September 2005. The sample was preserved in $4 \%$ formalin. Algal samples were not collected due to very heavy flooding of River in the month of July 2005. The methods described in the 'Standard Methods for the Examination of Water and Wastewater (1985)' as prescribed by American Public Health Association (APHA), American Water Works Association (AWWA), and Water Pollution Control Federation (WPCF) was adopted. The identification of phytoplankton was done with the help of standard books and monographs (Smith, 1950; Prescott, 1954; Ward and Whipple, 1959; Prescott, 1951). Phytoplankton was counted by drop count method and the results were converted to organisms per $\mathrm{ml}$ of water. The present investigation tolerant genera and species were recorded for three sites of River. Algal communities made the assessment of water quality of three sites of River.

\section{RESULTS AND DISCUSSION}

Palmer (1969) made the first major attempt to identify and prepare a list of genera and species of algae tolerant to organic pollution. Pollution tolerant genera and species of four groups of algae from three sites were encountered by us investigation that also figure in palmer's list of pollution tolerant is represented in Table 1 and 2. The most pollution tolerant species, according to Palmer's index are listed in Table 3. Out of a total 38 genera and 39 species pollution tolerant, 18 genera belonging to Chlorophyceae, 11 genera belonging to Bacillariophyceae, 6 genera of Cyanophyceae, and 3 genera belonging to Euglenophyceae were noted (Table 1, 2). Palmer's (1969) has shown that the genera like Oscillatoria, Euglena, Scenedesmus, Chlamydomonas, Navicula, Nitzschia, Stigeoclonium, and Ankistrodesmus are the species found in organically polluted waters supported by Gunale and Balakrishnan (1981). Similar genera are recorded in the present investigation. Ratnasabapathy (1975) has 
reported that Oscillatoria, Euglena, Chlorella and Ankistrodesmus are typical inhabitants of heavily polluted waters. Patrick (1965) concluded that Euglena and Oscillatoria are highly pollution tolerant genera and, therefore, reliable indicators of
Eutrophication in present study similar of these genera with very high grade points of Palmer's scale, like Euglena viridis, Euglena gracilis, Oscillatoria limosa, Oscillatoria chlorine and Oscillatoria tenuis were recorded.

Table 1. Pollution Tolerant Genera of Algae from Three Sites of Mutha River in Order of Decreasing Emphasis (Palmer, 1969)

\begin{tabular}{|l|ccc|}
\hline Algal Taxa /Sites & $\mathbf{1}$ & $\mathbf{2}$ & 3 \\
\hline Oscillatoria & + & + & + \\
Navicula & + & + & + \\
Euglena & - & + & + \\
Scenedesmus & + & + & + \\
Nitzschia & - & + & + \\
Phacus & + & + & + \\
Fragilaria & - & - & + \\
Pediastrum & + & + & + \\
Cymbella & + & + & + \\
Closterium & + & + & + \\
Spirogyra & + & - & - \\
Cosmarium & + & + & + \\
Coelastrum & + & + & + \\
Synedra & - & + & + \\
Gomphonema & - & + & + \\
Stigeoclonium & - & + & + \\
Chlamydomonas & - & + & + \\
Anabena & - & - & + \\
Melosira & + & + & + \\
Lyngbya & - & + & + \\
\hline
\end{tabular}

\begin{tabular}{|l|ccc|}
\hline Algal Taxa /Sites & $\mathbf{1}$ & $\mathbf{2}$ & 3 \\
\hline Pinnularia & & & \\
Spirulina & - & + & + \\
Pandorina & - & - & + \\
Ankistrodesmus & - & + & + \\
Chlorella & - & - & + \\
Cyclotella & - & - & + \\
Endorina & - & - & + \\
Phormidium & - & - & + \\
Trachelomonas & - & - & + \\
Actinastrum & - & + & + \\
Chlorogonium & - & + & + \\
Oocystis & - & - & + \\
Cladophora & - & - & + \\
Tribonema & - & - & + \\
Gonium & - & + & + \\
Achnanthes & - & - & + \\
Asterionella & - & + & - \\
Ulothrix & - & + & + \\
& & & \\
\hline
\end{tabular}

The pollution tolerance of Stigeoclonium tenue was already documented. Mclean (1974), Mclean and Benson-Evans as well as Gunale and Balakrishnan (1981) have shown that Stigeoclonium tenue is an indicator of organic pollution and tolerance to heavy metals which is recorded in present investigation. Gunale and Balakrishnan (1981) showed Schizomeris leibleinii as an indicator of eutrophication which is recorded in present investigation. Schizomeris leibleinii was also observed in the Mutha-Mula complex (Sangam Bridge) growing luxuriantly wherever was an inflow of domestic sewage. It occurred practically throughout the study. The association of these algae with Stigeoclonium tenue therefore clearly indicates that this algae also has a similar high tolerance for organic pollution and heavy metals. In present investigation at Sangam Bridge and Garware Causeway showed an abundance of phytoplankton throughout the study and even more interestingly, a number of genera and species of pollution tolerant algae with high Palmer's grade points clearly indicating a high degree of eutrophication. Pearsal1 (1932) was the first to show a clear correlation between organic pollution and blue-green algae and the centric diatoms. Because of the planktonic forms namely Pandorina, Scenedesmus, Navicula, Chlorella, Spirulina,
Anabaena, Eudorina, Melosira, Closterium, Cosmarium are observed in present study which are the indicators of the organically pollution tolerant species. According to Palmer's index of pollution for rating of water samples as high or low organically polluted at different sites were examined. The total score of site 2 (mainstream) and site 3 (downstream) was greater than 20 indicating the confirmed high organic pollution. While the total scores of site 1 (Upstream) was less than 20 indicating probable high organic pollution.

In the present investigation, the dominant of Bacillariophyceae like, Navicula, Nitzschia, Gomphonema, Synedra and Fragilaria was observed at Sangam Bridge. Similar observation where tallied by Cholonky (1968) he gave detailed account of dominant species of diatoms being used as indicators of water quality. In our study, at upstream site (Vitthalwadi) are characterized by abundance of green algal flora like, Zygnema, Spirogira, Mougeotia, Euastrum, Staurastrum, etc. these spots are comparatively less polluted. It was also supported by Venkateswarlu and Reddy (1985) and Verma and Mohanty (1994).The algal flora of polluted water bodies (Sangam bridge and Garware Causeway ) shows the dominance of blue green and diatoms like, 
Oscillatoria, Lyngbya, Anabena, Microcystis, Navicula, Nitzschia, Synedra, Gomphonema through out the investigation many green algae like, Pandorina, Endorina, Scenedesmus, Stigeoclonium, Ankistrodesmus, Chlamydomonas, Pediastrum, Coelastrum, etc. also occur abundantly and frequently. The present investigation on freshwater the most pollution tolerant species of Euglena, Oscillatoria, Navicula, Nitzschia, Stigeoclonium, Schizomeris, Ankistrodesmus, Scenedesmus,
Chlamydomonas, etc. were recorded maximum at site 3 (Sangam bridge) indicating the highest degree of organic pollution. Because of our investigation, the trend of increase in organic pollution from site 1 on wards in downstream of River was observed in present study as it was also supported by the data of physico-chemical analysis of water. The similar observations were encountered by Hosmani and Bharati (1980).

Table 2. Pollution Tolerant Species of Algae from Three Sites of Mutha River in Order of Decreasing Emphasis (Palmer, 1969)

(+) Present and (-) Shows absence of species

\begin{tabular}{|l|lll|}
\hline Algal Taxa / Site & $\mathbf{1}$ & $\mathbf{2}$ & 3 \\
\hline Navicula cuspidate & + & + & + \\
Fragilaria capucina & + & + & - \\
Oscillatoria formosa & - & - & + \\
Stigeoclonium tenue & - & + & + \\
Pandorina morum & - & + & + \\
Nitzschia palea & - & - & + \\
Scenedesmus quadricauda & - & + & + \\
Melosira varians & - & - & + \\
Nitzschia acicularis & - & + & - \\
Synedra acus & - & + & + \\
Oscillatoria chlorine & - & + & + \\
Oscillatoria brevis & - & + & + \\
Navicula viridural & - & + & - \\
Euglena gracilis & - & + & + \\
Oscillatoria chalybea & - & + & + \\
Navicula crptocaphala & - & - & + \\
Synedra ulna & - & + & + \\
Cyclotella meneghiniana & - & - & + \\
Chlorella vulgaris & - & - & + \\
Oscillatoria limosa & - & - & + \\
\hline
\end{tabular}

Many researchers extensively used Nygaard's (1949) indices to understand the quality criteria of the water (Ragothaman and Jaiswal, 1995; Trivedy 1986). The Nygaard's trophic state indices for three sites of Mutha River are represented in Table 4. Nygaard's indices of different groups of algae viz Myxophycean, Chlorophycean, Diatoms, Euglenophycean and Compounds are used to get a meaningful evaluation of the extent of pollution in the water. The trophic state indices of Myxophycean in sites 2 and 3 are indicating Eutrophic nature of fresh water. While this indices shown oligotrophic nature of water at upstream site (Vitthalwadi). The trophic state indices of Chlorophycean group at three sites are indicates Eutrophic nature of water bodies. The trophic state indices of Diatoms indicate oligotrophic nature of water at site 1 and Eutrophic at sites 2 and 3. The trophic state indices of Euglenophycean at Vitthalwadi were shown oligotrophic nature of water, while Eutrophic nature of fresh water was observed at Garware Causeway and Sangam Bridge. The compound index, which had widest range and was very sensitive holds good index for assessing the eutrophication, were shown Eutrophic nature of water at three sites of Mutha River. The similar observation was encountered by earlier workers, Tayelor et al., (1977), Gunale and Balakrishnan (1981). As a result of

\begin{tabular}{|l|lll|}
\hline Algal Taxa / Site & $\mathbf{1}$ & $\mathbf{2}$ & 3 \\
& & & \\
\hline Phacus pleuronects & - & + & + \\
Euglena viridis & - & - & + \\
Endorian elegans & - & - & + \\
Scenedesmus obiquus & - & + & - \\
Pediastrum boryanum & - & - & + \\
Melosira granulate & - & + & + \\
Trachelomonas volvocina & - & - & + \\
Euglena acus & - & - & + \\
Scenedesmus dimorphus & - & - & + \\
Actinastrum hantzschii & - & + & + \\
Ankistrodesmus falcatus & - & - & + \\
Cladophora glomerata & - & - & + \\
Coelastrum microporum & + & - & - \\
Euglena oxyuris & - & - & + \\
Closterium acerosum & - & + & - \\
Euglena intermedia & - & - & + \\
Gonium pectorala & - & + & + \\
Chlorogonium elongatum & - & + & + \\
Pediastrum duplex & + & - & - \\
\hline
\end{tabular}

our critical studies, we do feel that it would be possible to grade waters with reference to the degree of organic pollution (eutrophication) by using a synthetic approach. i.e. a consideration of the number of pollution indicator organisms of the different categories present along with the Nygaard quotient which would give the community picture as well. Although before a precise system can be worked out, much more information regarding the tolerance of various algae to levels of pollution and critical evaluations of the phytocoenoses of such polluted waters would be needed. However, as pointed out earlier the increasing urbanization and industrialization in this area is posing a very serious threat in that it is creating an ever increasing quantity of effluents of all types being added to Mutha waters which twining to eutrophicated. Results show shift in algal community from upstream to downstream due to increasing organic enrichment. This was further confirmed by using Palmer's and Nygaard indices.

Acknowledgments: Authors are grateful to the Head, Department of Environmental Sciences University of Pune, for providing necessary facilities and encouragement. Thanks also extended to Prof. Dr M. Z. Ahmadi for valuable help and encouragement 
.Table 3. Pollution Index at Three Sites of Mutha River (Palmer, 1969)

\begin{tabular}{|l|cccc|}
\hline Algal Taxa./Sites & $\begin{array}{c}\text { Pollution } \\
\text { Index }\end{array}$ & $\mathbf{1}$ & $\mathbf{2}$ & $\mathbf{3}$ \\
\hline Ankistrodesmus & 2 & - & 2 & 2 \\
Chlamydomonas & 4 & - & 4 & 4 \\
Chlorella & 3 & - & - & 3 \\
Closterium & 1 & 1 & 1 & 1 \\
Cyclotella & 1 & - & - & 1 \\
Euglena & 5 & - & 5 & 5 \\
Gomphonema & 1 & - & 1 & 1 \\
Melosira & 1 & 1 & 1 & 1 \\
Navicula & 3 & 3 & 3 & 3 \\
Nitzschia & 3 & - & 3 & 3 \\
Oscillatoria & 5 & 5 & 5 & 5 \\
Pandorina & 1 & - & 1 & 1 \\
Phacus & 2 & 2 & 2 & 2 \\
Phormidium & 1 & - & - & 1 \\
Scenedesmus & 4 & 4 & 4 & 4 \\
Stigeoclonium & 2 & - & 2 & 2 \\
Synedra & 2 & - & 2 & 2 \\
\hline Total Score & & 16 & 36 & 41 \\
\hline
\end{tabular}

Table 4. Nygaard's Trophic Status Indices of Mutha River

\begin{tabular}{|l|l|l|l|l|}
\begin{tabular}{|l|l|l|} 
Indices Nygaard's \\
index
\end{tabular} & $\begin{array}{c}\text { Trophic Status } \\
\text { Indices } \\
\text { Eutrophic } \\
\text { Oligotrophic }\end{array}$ & $\begin{array}{c}\text { Site } \\
1\end{array}$ & $\begin{array}{c}\text { Site } \\
2\end{array}$ & 3 \\
\hline Myxophycean & $0.0-0.4$ & 1.15 & 7.37 & 9.88 \\
& $0.1-3.0$ & 1.38 & 4.12 & 5.44 \\
\hline Chlorophycean & $0.0-0.7$ & & & \\
\hline Diatoms & $0.2-9.0$ & 0.066 & 0.17 & 0.20 \\
\hline Euglenophycean & $0.0-0.3$ & & & \\
\hline Compound & $0.0-1.75$ & 0.15 & 0.27 & 0.33 \\
& $1.2-2.5$ & 3.07 & 16 & 21.88
\end{tabular}

\section{REEFERENCE}

APHA (1985). Standard methods for the examination of water and wastewater. APHA, AWWA and WPCF. $16^{\text {th }}$ ed. American public progress Springfield, New York.

Bhatt, L R; Lacoul, P; Lekhal, H D; Jha, P K (1999). Physico-chemical characteristic and phytoplanktons for Taudha lake, Kathmandu. Poll. Res. 18 (4): 353-358.

Cholonoky, B J (1968). Die Okologie der Diatomeen in Binery Ewassera. J. Cramex, Germany. 699 pp.

Dwivedi, B K; Pandey, G C (2002). Physicochemical factors and algal diversity of two ponds (Girija Kund and Maqubara Pond), Faizabad, India. Poll. Res. 21 (3): 361- 369.
Gunale, V R; Balakrishnan, M S (1981). Biomonitoring of eutrophication in the Pavana, Mula and

Mutha Rivers flowing through Poona. Indian J. Environ. Hlth. 23 (4): 316-322.

Hosmani, S P; Bharati, S G (1980). Algae as indicators of organic pollution. Phyko. 19 (1): 23-26.

Joubert, G (1980). A bioassay application for quantitative toxicity management using the green algae, Selenastrum Capricornutum .Water Res. 14: 1759-1763.

Karr, J R; Allen, J D; Benke, A C (2000). River conservation in the United States and

Canada. In: Boon, P J; Davies, B R; Petts, G E (eds.) Global perspectives on River 
conservation. Science, Policy, and Practice. Wiley, New York. pp 3-39.

Mclean, R O (1974). Tolerance of Stigeoclonium tenue Kuetz. to heavy metals in south Wales. Bri. Phycol. 9: 91-98.

Nygaard, G (1949). Hydrobiological studies on some Danish ponds and lakes II. The quotient hypothesis and some new or little known phytoplankton organisms. Dat. Kurge. Danske. Vid. Sel. Biol Skr 7: 1-293.

Palmer, C M (1969). A composite rating of algae tolerating organic pollution. Phyco. 15: 78-82.

Patrick, R (1965). Algae as indicator of pollution. In biological problems in water pollution. $3^{\text {rd }}$ Seminar Bot. A. Tuft. Sanitory Eng. Centre Cincinati Ohio. pp 223-232.

Pearsall, W H (1932). Phytoplankton in the English lakes II. Ecol. 22:241-262

Prescott, G W A (1951). Algae of the western Great lakes area. Cranbrook Institute of Science. Bulletin No. 31. 946 pp.

Prescott, G W (1954). How to know fresh water algae. Won. C. Brown CO. Dubuque. Ragothaman, G; Jaiswal, R N (1995). Hydrobiology of Tapti River from Jalgaon region (Maharashtra) with reference to phytoplankton. Poll. Res. 14 (2):181-194.

Ratnasabapathy, M (1975). Biological aspects of Wardieburn sewage oxidation pond. Malaysian Sci. 3 (a): 75-87.

Saha, S B; Bhattacharya, S B; Choudhury, A (2000). Diversity of phytoplankton of sewage pollution brakish water tidal ecosystems. Environ. Biol. 21 (1): 9-14.
Stevenson, R J; Pan, Y (1999). Assessing environmental conditions in Rivers and streams using diatoms. In: Stoermer, E F; Smol, J P (eds.) The diatoms. Applications for the environmental and earth sciences. Cambridge University Press, Cambridge. pp 11-40.

Sudhaker, G; Joyothi, B; Venkateswarlu, V (1994). Role of diatom as indicator of polluted gradients. Environ. Moni. and Assessment 33:85-99.

Smith, G M (1950). Fresh water algae of United States of America. MC. Grew Hill, New York.

Tayelor, W D; Hiatt, F A; Hern, S C; Hilgert, J M; Lambou, V W; Morris, $\mathrm{F}$ A; Thomas, R W; Morris, M K; Williams, L R (1977). Distribution of phytoplankton in Floride lakes, U. S. EPA. National Eutrophication Survey Working Paper No. 679 iii $^{+} 1113$ pp.

Trivedy, R K (1986). Role of algae in biomonitoring of water pollution. Asian Environ. 8 (3): 31-42.

Venkateswarlu, V; Reddy, M (1985). Algae as biomonitors in River ecology. Sym. Biominitoring State Envir. pp. 183-189.

Verma, J P; Mohanty, R C (1994). Evaluation of water quality on the St. Joseph River (Michigan and Indiana U. S. A.) by 3 methods of algal analysis. Hydrobiolo. 48:145-173.

Ward, H B; Whipple, G C (1959). Fresh water biology. $2^{\text {nd }}$ Ed. John Wiley and Sons, New York. 